\title{
Immunogenicity and crossreactivity of antibodies to SARS-CoV-2 nucleocapsid
}

\section{protein}

Carlota Dobaño ${ }^{1,2}$, Rebeca Santano ${ }^{1}$, Alfons Jiménez ${ }^{1,2}$, Marta Vidal ${ }^{1}$, Jordi Chi ${ }^{1}$, Natalia Rodrigo Melero ${ }^{3}$, Matija Popovic ${ }^{3}$, Rubén López-Aladid ${ }^{4}$, Laia Fernández-Barat ${ }^{4}$, Marta Tortajada $^{5}$, Francisco Carmona-Torre ${ }^{6,7}$, Gabriel Reina ${ }^{8}$, Antoni Torres ${ }^{4,9}$, Alfredo Mayor ${ }^{1,2,10}$, Carlo Carolis $^{3}$, Alberto L. García-Basteiro ${ }^{1,10,11}$, Ruth Aguilar ${ }^{1}$, Gemma Moncunill $^{1 \star}$, Luis Izquierdo ${ }^{1 *}$

${ }^{1}$ ISGlobal, Hospital Clínic - Universitat de Barcelona, Barcelona, Catalonia, Spain.

${ }^{2}$ Spanish Consortium for Research in Epidemiology and Public Health (CIBERESP), Spain.

${ }^{3}$ Biomolecular screening and Protein Technologies Unit, Centre for Genomic Regulation (CRG), The Barcelona Institute of Science and Technology, Barcelona, Spain.

${ }^{4}$ Cellex Laboratory, CibeRes (Centro de Investigación Biomédica en Red de Enfermedades Respiratorias, 06/06/0028), Institut d'Investigacions Biomèdiques August Pi i Sunyer

(IDIBAPS), Hospital Clinic, Barcelona, Spain.

${ }^{5}$ Occupational Health Department, Hospital Clínic, Universitat de Barcelona, Barcelona, Spain.

${ }^{6}$ Infectious Diseases Division and Clinical Microbiology, Clínica Universidad de Navarra, Pamplona, Spain.

${ }^{7}$ IdiSNA, Navarra Institute for Health Research, Spain.

${ }^{8}$ Clínica Universidad de Navarra, Navarra Institute for Health Research, Pamplona, Spain.

${ }^{9}$ Pneumology Service, Hospital Clinic, Barcelona, Spain.

${ }^{10}$ Centro de Investigação em Saúde de Manhiça (CISM), Maputo, Mozambique.

${ }^{11}$ International Health Department, Hospital Clinic, Universitat de Barcelona, Spain.

${ }^{*}$ Contributed equally

Corresponding authors: Carlota.dobano@isglobal.org; Gemma.moncunill@isglobal.org 
medRxiv preprint doi: https://doi.org/10.1101/2020.12.19.20248551; this version posted December 22, 2020. The copyright holder for this

\section{Conflict of interest statement}

The authors have declared that no conflict of interest exists.

\section{ABSTRACT}

COVID-19 patients elicit strong responses to the nucleocapsid $(\mathrm{N})$ protein of SARS-CoV-2 but binding antibodies are also detected in prepandemic individuals, indicating potential crossreactivity with common cold human coronaviruses (HCoV) and questioning its utility in seroprevalence studies. We investigated the immunogenicity of the full-length and shorter fragments of the SARS-CoV-2 N protein, and the crossreactivity of antibodies with HCoV. We indentified a C-terminus region in SARS-CoV2 $\mathrm{N}$ of minimal sequence homology with $\mathrm{HCoV}$ that was more specific and highly immunogenic. IgGs to the full-length SARS-CoV-2 N also recognised N229E N, and IgGs to HKU1 N recognised SARS-CoV-2 N. Crossreactivity with SARS-CoV-2 was stronger for alpha- rather than beta-HCoV despite having less sequence identity, revealing the importance of conformational recognition. Higher preexisting IgG to OC43 N correlated with lower IgG to SARS-CoV-2 in rRT-PCR negative individuals, reflecting less exposure and indicating a potential protective association. Antibodies to SARS-CoV-2 N were higher in patients with more severe and longer symptoms and in females. IgGs remained stable for at least 3 months, while IgAs and IgMs declined faster. In conclusion, $\mathrm{N}$ is a primary target of SARS-CoV-2-specific and HCoV crossreactive antibodies, both of which may affect the acquisition of immunity to COVID-19.

Keywords:

Antibody; immunoassay; serology; SARS-CoV-2; COVID-19; IgM; IgA; IgG; Luminex; quantitative suspension array technology; multiplex; nucleocapsid; human coronavirus; 229E; NL63; HKU1; OC43; crossreactivity. 
medRxiv preprint doi: https://doi.org/10.1101/2020.12.19.20248551; this version posted December 22, 2020. The copyright holder for this preprint (which was not certified by peer review) is the author/funder, who has granted medRxiv a license to display the preprint in perpetuity.

All rights reserved. No reuse allowed without permission.

\section{INTRODUCTION}

The identification of the antigens and epitopes that induce antibody responses after exposure to SARS-CoV-2 infection is one of the requirements to estimate the seroprevalence in a population. In addition, it is also essential to understand immunity to COVID-19 disease. Previous knowledge on other related coronaviruses and the prompt sequencing of the SARS-CoV-2 genome early in the pandemic allowed to identify the spike (S) (1) and the nucleocapsid (N) (2) structural proteins as major targets of antibodies. Consequently, both antigens constituted the basis for most immunoassays developed to study COVID-19 distribution and protective immune responses. The surface glycoprotein $\mathrm{S}$, which contains the receptor binding domain (RBD), has a better known function in immunity (3-5) and is the leading antigen candidate for vaccine development $(6,7)$. $\mathrm{N}$ is smaller than $\mathrm{S}$, lacks a glycosylation site, and is extensively used in leading serodiagnostics kits (8-11) due to its abundant expression during infection (12-14) and early antibody response $(15,16)$, but its immunological relevance is less established. The pattern of antibody responses to $S$ compared to $\mathrm{N}$ may vary according to disease severity (17) and age (18). $\mathrm{N}$ forms ribonucleoprotein complexes during the virion assembly process by binding to the viral RNA genome and packing it into long helical structures (19). Its main function is to regulate viral RNA transcription during replication, promoting the synthesis of its own proteins (14) while interfering with the metabolism $(19,20)$, protein translation $(21)$ and proliferation (22) of the infected host cell. During the process of infection, $\mathrm{N}$ dissociates itself from the genome and is exposed to the host immune system (23), and its high immunogenicity has also prompted its exploration as vaccine target $(13,24)$.

We recently developed a multiplex quantitative suspension array assay using the XMAP Luminex technology (25). We included antigen fragments of S, N and membrane (M) SARSCoV-2 proteins to establish the utility of each construct for seroprevalence and correlates of immunity studies. Initial investigations using plasma or serum samples from individuals infected with SARS-CoV-2 and prepandemic samples (negative controls), showed different 
medRxiv preprint doi: https://doi.org/10.1101/2020.12.19.20248551; this version posted December 22, 2020. The copyright holder for this

levels of immunogenicity and specificity across the antigens and fragments tested. Even though antibodies to full-length $N(N$ FL) constructs were usually high in adult COVID-19 cases, moderate to high responses were frequently detected in samples collected before the pandemic (25), as it had been reported before also for SARS-CoV-1 samples (26). This questioned the use of N FL for seropositivity calculations that were consequently restricted to S-based antigens in our initial evaluations (27). We hypothesized that such antibody signals in negative controls, more prominent for $\mathrm{N}$ than $\mathrm{S}$ antigens, reflected crossreactivity with human coronaviruses of the common cold ( $\mathrm{HCoV})$ due to highly conserved regions, rather than nonspecific or polyreactive responses. The HCoV include alphacoronaviruses (229E and NL63) and betacoronaviruses (HKU1 and OC43). In fact, increasing number of reports in the literature are consistent with some antibodies to HCoV being crossreactive with the betacoronaviruses SARS-CoV-2 and SARS-CoV-1 (28-32). Interestingly, significant protein similarity between SARS-CoV-1, SARS-CoV-2 and other HCoV has been reported for N, including a highly conserved motif in the N-terminal (NT) half of the protein (FYYLGTGP) (33) and relevant immunodominant epitope regions (24, 34). Likewise, preexisting SARSCoV-2-specific T cells have also been reported and attributed to crossreactivity with HCoV previously encountered (35-39).

A key question is the relevance of those preexisting antibodies on acquisition of COVID-19 immunity. Is this crossreactivity sufficient to protect against disease? (40). If this is the case, it could be one of the reasons why children may be more protected than older adults (41) $(42,43)$. Alternatively, these preexisting crossreactive antibodies could interfere with the development and/or maintenance of effective levels of SARS-CoV-2 antibodies $(44,45)$ and, even worse, they could have a negative impact by mediating antibody-dependent disease enhancement $(A D E)(46,47)$, which could be associated with severe prognosis $(48,49)$. Our study aimed to better characterize the immunogenicity, specificity and crossreactivity of anti-N antibodies from SARS-CoV-2 and 229E, HKU1, NL63 and OC43 HCoV, measured simultaneosuly. To this end, we tested different antigenic fragments in multiplex and different Ig isotypes, and compared their relative immunogenicity in prepandemic and pandemic 
medRxiv preprint doi: https://doi.org/10.1101/2020.12.19.20248551; this version posted December 22, 2020. The copyright holder for this

samples, including SARS-CoV-2 positive cases. In addition, we aimed to better understand the demographic, clinical and epidemiological variables affecting the levels of antibodies to $\mathrm{N}$ SARS-CoV-2 in exposed people. Our study helps addressing the extent and characteristics of this crossreactivity in the immune response to COVID-19 and the utility of various N-based antigens in serodiagnostics and seroprevalence studies.

\section{RESULTS}

\section{Immunogenicity, specificity and seropositivity of SARS-CoV-2 N antibodies}

Plasmas from individuals diagnosed with COVID-19 had statistically significantly higher levels of $\lg G, \lg A$ and $\lg M$ to the $F L$ as well as the NT and C-terminal (CT) domains of SARS-CoV-2 N protein (Figure S1) than prepandemic plasmas (Figure 1). Levels were statistically significantly higher in patients who were hospitalized compared to nonhospitalized (asymptomatics and mild cases) (Figure 1A). However, prepandemic plasmas also contained $\lg G$, $\lg M$ and $\lg A$ antibodies recognizing $N$ antigens. In the case of $\lg G$, the responses against N FL were the highest, followed by the N NT and N CT domains. This high reactivity of negative control plasmas resulted in a higher seropositivity cutoff and lower seroprevalence estimates for IgG to N FL in our cohort of health care workers, with $10.1 \%$ at M1 (Figure S2A) compared with 11.3\% for RBD (27). Higher plasma dilutions (1/3500 vs. $1 / 500$ ) reduced antibody levels proportionally more in prepandemic than pandemic samples, increasing signal-to-noise ratio, sensitivity and overall seropositivity (Figure S2B). Nevertheless, seroreactivity in prepandemic samples was still patent, which could be attributed to the presence in our antigens of stretches of immunogenic aminoacid sequences similar to other HCoV $(24,28)$. Searching for SARS-CoV-2 specific responses, we tested a CT-short protein and a CT-peptide from $\mathrm{N}$ that had a lower percentage of identity with HCoVs N (Figure S1). The shorter N CT constructs were immunogenic in pandemic positive samples and less seroreactive in prepandemic samples than N FL, with higher signal-to- 
medRxiv preprint doi: https://doi.org/10.1101/2020.12.19.20248551; this version posted December 22, 2020. The copyright holder for this

noise ratios obtained (Figure 1B). Additional information on the serological characterization of the rest of N FL constructs is provided in the Supplemental material, Figures S3 \& S4.

\section{Crossreactivity of IgG antibodies to SARS-CoV-2 and HCoV N FL proteins}

To test whether the antibodies recognizing SARS-CoV-2 $\mathrm{N}$ antigens in negative samples could be due to crossreactivity with HKU1, OC43, NL63 or 229E HCoV, we compared the patterns of $\lg G$ responses to N FL from the five coronaviruses in prepandemic and COVID19 samples at two timepoints, also including the SARS-CoV-2 N CT-short fragment. Overall, anti-N IgG levels to SARS-CoV-2 were significantly higher in COVID-19 cases vs.

prepandemic samples compared to HCoV lgG levels, which were similar or slightly higher in pandemic positive vs. prepandemic samples, like for NL63 (Figure 2A). This pattern indicates both high immunogenicity of SARS-CoV-2 $\mathrm{N}$ antigens in COVID-19 samples, but also some level of crossreactivity against some HCoV N antigens. Furthermore, data support the higher SARS-CoV-2-specificity of the IgG response to the CT-short portion of $\mathrm{N}$ because IgG levels in prepandemic samples were the lowest and similar to pandemic real time reverse-transcriptase polymerase chain reaction (rRT-PCR) negative (Figure 2A). Pandemic samples from rRT-PCR negative health care workers had significantly higher levels of IgG to N FL, but not N CT-short, than prepandemic samples and significantly lower levels than rRTPCR positive individuals.

In prepandemic samples, IgG levels to HKU1 HCoV N FL were statistically significantly higher in samples with higher lgG levels to SARS-CoV-2 N FL (Figure 2B), and there was a significant correlation (rho $=0.35, p=0.0065$ ) between N FL IgG responses of HKU1 HCoV to SARS-CoV-2 and to a lesser extent with NL63 HCoV (Figure 3A), suggestive of crossreactivity. In pandemic rRT-PCR positive samples, IgG levels to 229E HCoV N FL were statistically significantly higher in samples with higher IgG levels to SARS-CoV-2 N FL

(Figures 2C), and there was a significant correlation of N FL IgG responses between SARSCoV-2 and 229E HCoV (rho=0.38-0.45, p<0.0024) (Figures 3A \& 3B). Correlation between N FL and N CT-short was higher and more significant in pandemic (rho $=0.79, p<0.001)$ and 
medRxiv preprint doi: https://doi.org/10.1101/2020.12.19.20248551; this version posted December 22, 2020. The copyright holder for this

rRT-PCR positive (rho=0.6, $\mathrm{p}<0.001$ ), compared to prepandemic and rRT-PCR negative samples, respectively (Figure 3A \& 3B). In contrast, there was a significant inverse correlation between OC43 HCoV and SARS-CoV-2 IgG levels in rRT-PCR negative pandemic samples (rho=-0.39, $\mathrm{p}=0.019$ ) (Figure 3B). Integrating the magnitude of responses to the HCoV N FL proteins, the correlation with SARS-CoV-2 N FL was statistically significant in pandemic ( $r h o=0.29, p=0.026$, Figure $3 B$ ) and $r R T-P C R$ positive samples (rho $=0.27, p=0.0084$, Figure $3 \mathrm{C}$ ), and it was higher and only significant for alpha(229E and NL63) than for beta-HCoV (229E and NL63) (Figure 3C). The correlation in prepandemic samples improved when OC43 beta-HCoV was excluded from the HCoV summation ( $r h o=0.25, p=0.053$ vs. rho $=0.2 p=0.13$ ), although IgG levels to $O C 43$ strongly correlated with those of alpha-coronaviruses (rho $=0.522$ for $229 \mathrm{E}$, rho $=0.503$ for NL63)

(Figure S5A). SARS-CoV-2 N FL levels correlated more significantly with N NT in prepandemic (rho=0.526) and with N CT in pandemic (rho>0.624) samples. The breadth of responses to human coronaviruses was heterogeneous among individuals, but patterns of antibodies to alpha- and beta-HCoV tended to cluster together (Figure S5B).

In individuals who became infected with SARS-CoV-2 from M0 to M1, IgG levels increased significantly for SARS-CoV-2 N FL $(p=0.015)$ and SARS-CoV-2 N CT-short $(p=0.031)$, while antibody profiles for $\mathrm{HCoV} \mathrm{N}$ proteins were variable (Figure 4). IgG to $\mathrm{N}$ from beta-HCoV tended to decrease or maintain, whereas IgG to N from alpha-HCoV (NL63 and 299E) increased in about half of individuals but overall not significantly due to low sample size and high variability. There did not seem to be a relationship between IgG levels at baseline and the change in levels at month (M)1. In uninfected individuals, IgG levels declined from $M 0$ to $\mathrm{M} 1$, significantly for 4 of $6 \mathrm{~N}$ antigens (Figure 4).

\section{Kinetics and determinants of antibody levels to SARS-CoV-2 N FL}

Having shown that SARS-CoV-2 infections induce a specific antibody response to the $\mathrm{N}$ antigen, despite having in some cases preexisting crossreactive antibodies due to prior exposure to $\mathrm{HCoV}$, we investigated the kinetics and demographic, clinical and 
medRxiv preprint doi: https://doi.org/10.1101/2020.12.19.20248551; this version posted December 22, 2020. The copyright holder for this

epidemiological variables associated with the levels of immunoglobulins to N FL. We analyzed samples from the cohort of health care workers followed up for 3 months in whom we had previously characterized RBD antibodies $(27,50)$. We performed two analyses, including (i) all individuals and (ii) only those who were seropositive for SARS-CoV-2 RBD antibodies and, therefore, with evidence of exposure to the virus. IgA and IgM to SARS-CoV$2 \mathrm{~N} \mathrm{FL}$ declined more markedly than IgG, which maintained high levels over the 3 months of study (Figure 5).

Having symptoms had a statistically significant association with higher $\lg A$ and $\lg G$ levels to SARS-CoV-2 N FL, and having a longer duration of symptoms had a statistically significant association with higher $\lg \mathrm{A}$ and $\lg \mathrm{M}$ levels to SARS-CoV-2 N FL (Figure 6A). IgA levels to SARS-CoV-2 N FL tended to be higher in older individuals, and IgM responses were statistically significantly higher in females than males (Figure 6B). No other clear associations were found for occupation or number of COVID-19 contacts.

\section{DISCUSSION}

Our study shows that SARS-CoV-2 infection induces specific $\lg M, \lg A$ and $\lg G$ antibody responses to epitopes located at both the NT and CT domains of the N protein, consistent with immunogenicity data reported in the literature $(15,20,51-53)$. All antibodies were of higher magnitude in patients with more severe clinical manifestations compared to those not requiring hospitalization, and in symptomatic compared to asymptomatic health care workers for $\lg G$ and $\lg A$. Longer duration of symptoms was associated with higher $\lg \mathrm{A}$ and $\lg \mathrm{M}$ levels, IgA levels tended to increase with age, and females had higher lgM levels.

Importantly, anti-N $\lg \mathrm{G}$ antibodies remained quite stable over a period of at least 3 months following mild or asymptomatic infection, while IgAs and IgMs declined faster, similar to SARS-CoV-2 RBD responses (50).

We also found that significant levels of $\lg G$, IgM and IgA recognising SARS-CoV-2 N proteins are present in so-called negative controls. This reactivity could limit the utility of the $\mathrm{N}$ antigen in seroprevalence studies, as the cutoff values for $\lg \mathrm{G}$ are higher and hence the 
medRxiv preprint doi: https://doi.org/10.1101/2020.12.19.20248551; this version posted December 22, 2020. The copyright holder for this

percentage of seropositive individuals may be underestimated, compared to calculations based on S antigens (27). However, point prevalence estimates during outbreaks could still be assessed with IgA and IgM to $\mathrm{N}$ proteins, as prepandemic samples have lower levels of such preexisting isotypes probably due to their shorter half-life, which is consistent with our kinetics data. The seroreactivity of $\mathrm{N}$ in negative controls also leads to lower specificity of SARS-CoV-2 diagnostic tests based on this antigen. To circumvent this, assays with truncated versions of $\mathrm{N}$ based on immunogenic regions have been developed (Roche, Abbot) $(8,10)$, as we have done here with N CT-short and N CT-peptide.

Among the three regions of N (NT RNA-binding domain, central linker, and CT dimerization domain), the NT and CT are the major structural and functional domains (19). Previous works carried out with SARS-CoV-1 N, sharing $>90 \%$ identity to SARS-CoV-2 N, revealed the presence of four main immunodominant regions (EP1-4) in different domains of the $\mathrm{N}$ protein (Figure S1 A) $(24,28,54)$. We focused on the B cell immunodominant domain EP4 showing a lower percentage of aminoacid identity with other HCoVs (residues 356-404) (Figure S1B) (55), which corresponds to the CT region of SARS-CoV-2 N. The N CT-short protein and the N CT-peptide presented epitopes that were more specific and still immunogenic, thus applicable for seroprevalence and immunity studies. Correlation between N FL and N CT-short was higher and more significant in pandemic and rRT-PCR positive compared to prepandemic and rRT-PCR negative samples, respectively, indicative of a specific response to SARS-CoV-2 N upon infection. Interestingly, pandemic rRT-PCR negative individuals had higher responses to N FL than prepandemic samples and significantly lower than rRT-PCR positive individuals. A possible explanation is that some of the rRT-PCR negative individuals might in fact have been exposed to SARS-CoV-2 despite being seronegative for RBD antibodies, but they could have been positive for $\mathrm{T}$ cell responses. This could indicate a higher sensitivity of $\mathrm{N}$ to detect lowresponders or early infections (28) and would imply that a much higher percentage of the population than estimated in the literature could have been exposed to SARS-CoV-2. Alternatively, the responses in rRT-PCR negatives could be due to crossreactivity with HCoV 
medRxiv preprint doi: https://doi.org/10.1101/2020.12.19.20248551; this version posted December 22, 2020. The copyright holder for this

in this group of health care workers that due to their occupation might be at higher risk of recent exposure to common colds at a period when they were still prevalent (FebruaryMarch). In contrast, the prepandemic samples had been collected at various times over the years but a large proportion in June 2008, some months after the cold season peak and the responses to HCoV are known to be shortlived (56). In line with this, levels of lgG to HCoV N FL decreased from M0 to M1 in seronegative and rRT-PCR negative individuals. It could also be a mixture of the two scenarios due to the wide range of antibody levels and overlap between groups. Therefore, the season of sample collection is an important variable to take into account. Consistent with crossreactive immune recognition with endemic and other emerging HCoVs, SARS-CoV-2-reactive CD4 ${ }^{+} \mathrm{T}$ cells have also been detected in $\sim 40-60 \%$ of unexposed individuals $(35,37)$. $\mathrm{N}$ is also a representative antigen for $\mathrm{T}$ cell response in vaccine studies, inducing SARS-CoV-specific T cell proliferation and cytotoxic activity (57, 58). However, other studies have reported a lack of $\mathrm{N}$ crossreactivity for antibody responses, with specificities $>94 \%$, which may be due to the protein regions included in the tests and/or the characteristics of the prepandemic controls included (59)(60). In the case of SARS-CoV1 , it has been reported that IgGs crossreact with the $\mathrm{N}$ antigen of endemic coronavirus, but only rarely in the other way round (42). To assess if antibodies to SARS-CoV-2 and HCoV N proteins were crossreactive and in which direction $(28,42,61)$, we tested the longer-lasting IgGs responses to N FL from 229E, NL63, HKU1 and OC43. These HCoV are widely distributed, with $229 \mathrm{E}$ and OC43 causing $15-29 \%$ of all common colds (62). $229 \mathrm{E}$, OC43 and NL63 tend to be transmitted predominantly during the winter season in temperateclimate countries, while NL63 (accounting for an estimated $4.7 \%$ of common respiratory diseases) have a Spring-Summer peak. Data on SARS-CoV-1 reported false-positive results obtained from a recombinant SARS-CoV-1 N ELISA due to the crossreactivity with antibodies to HCoV-OC43 and HCoV-229E $(26,33)$. Our data suggest that IgGs to SARSCoV-2 N also recognise N229E N, and that IgGs to HKU1 N recognise SARS-CoV-2 N, but not strongly. IgG levels to NL63 N were higher in pandemic positive vs. prepandemic samples but similar for other HCoVs. Correlations of SARS-CoV-2 N CT-short with HCoV N 
medRxiv preprint doi: https://doi.org/10.1101/2020.12.19.20248551; this version posted December 22, 2020. The copyright holder for this

FL were similar to those seen for N FL. When combining all HCoV N FL IgG levels, the positive correlation with SARS-CoV-2 N FL responses improved by excluding OC43. IgG responses to OC43 $\mathrm{N}$ correlated the least to SARS-CoV-2 in the rest of analyses, although it had a highly significant correlation with the alpha-HCoV 229E and NL63, in contrast to other reports (62). Interestingly, in rRT-PCR negative pandemic samples, there was a significant inverse correlation with IgG to OC43 HCoV that is the beta-HCoV with the highest sequence homology with SARS-CoV-2 N protein, suggesting a potential role on immunity. If preexisting IgG to OC43 bind to SARS-CoV-2, high antibody levels could neutralize SARS-CoV-2 infection upon exposure, resulting in sterile protection or low viral loads below the rRT-PCR detection threshold (rRT-PCR negative) that translates into low/no exposure and consequently less antibodies to SARS -CoV-2. If rRT-PCR individuals had not been exposed at all to SARS-CoV-2 (RBD seronegatives), then what would be measured as SARS-CoV-2 IgG might be lgG from crossreactive HCoVs. Nevertheless, a limitation of this study is that the design and sample size did not allow unraveling the potential effect of baseline HCoV antibodies on the acquisition of COVID-19 immunity (63), which will be addressed in future longitudinal follow up analysis of our cohorts. This effect could be neutral, positive (boost of responses) or negative, whereby having antibodies to certain viruses could adversely determine the profile of responses upon SARS-CoV-2 infection ('original antigenic sin') (44, 45,48 ) or interfere by antigen masking. Findings from a recent study argue against a protective role for crossreactive HCoV T cells in SARS-CoV-2 infection (37). In our study, we speculate that preexisting OC43 HCoV IgGs could be protective and, as a result, incoming SARS-CoV-2 infections would be more controlled and thus fewer antibodies induced against them.

Unexpectedly, higher serological correlations were consistently obtained for SARS-CoV-2 and alpha- rather than beta-HCoVs despite having less homology at the primary aminoacid sequence level. The reactivity of the alpha- and beta-HCoVs clustered together within families, also by PCA analysis (data not shown). Therefore, it appears that crossreactivity is also and mostly driven by homologies at the conformational rather than the linear level. 
medRxiv preprint doi: https://doi.org/10.1101/2020.12.19.20248551; this version posted December 22, 2020. The copyright holder for this

Overall, data indicated various degrees of moderate crossreactivity for SARS-CoV-2 and HCoV N antigens, but patterns were heterogeneous and not very strong, possibly as a result of a complex polyclonal response in which different epitopes in the various viral antigens would have a wide spectrum of serological recognition and mixed binding avidities. Our study had some limitations. We did not have access to samples from HCoV infected (rRT-PCR positive) individuals and thus the crossreactivity among the $\mathrm{N}$ antigens could not be fully assessed (64). In addition, we did not test IgG responses to other domains of $\mathrm{N}$ (like the NT that has significant sequence homologies except for a small aminoacid region) or other structural proteins (54). Our preliminary results show that crossreactivity may also exist for $M$ and S2 (60), due to antibody recognition in some prepandemic samples, as it had been similarly described for SARS-CoV infections $(65,66)$. In fact, different antigens could have different levels of crossreactivity, as seen in a recent study of HCoV S antibody responses that reported an increase in IgG to OC43 (but not 229 or NL63) S proteins with SARS-CoV-2 infection (67). This observation contrasts with our data that suggested boost of $\mathrm{N}$ IgG from M0 to M1 for 229 and NL63 but not for OC43. Other respiratory pathogens that are common coinfections may also have crossreactivity with SARS-CoV-2 and partially explain our results (68).

In conclusion, the N protein of SARS-CoV-2 is immunogenic but it is also recognised by partially crossreactive HCoV antibodies. More specific epitopes are located in the N CT-short region and could be used for seroprevalence and diagnostics purposes. Future larger prospective studies should determine whether the $\mathrm{N}$ antigen is a target of protective immune responses to COVID-19 and therefore a promising vaccine candidate together with S, and the role of preexisting $\mathrm{HCoV}$ antibodies in acquired immunity.

\section{METHODS}

\section{Antigens}


medRxiv preprint doi: https://doi.org/10.1101/2020.12.19.20248551; this version posted December 22, 2020. The copyright holder for this

SARS-CoV-2. Heterologously expressed N FL protein was either purchased from a commercial source (GenScript, Z03480), or purified in house after HEK cell (69) or Escherichia coli expression (25). Furthermore, two E. coli expressed His-tagged N protein constructs comprising the NT domain (residues 43-180) and CT domain (residues 250-360) were purified by affinity chromatography, as described (25). A shorter fragment of the CT region (CT-short), with a lower percentage of identity with other $\mathrm{HCoVs}$ and located within a putative $\mathrm{N}$ protein immunodominant region (EP4, residues $348-416)(24,28)$, was also heterologously expressed in E. coli cells and His tag-purified, as described (25). Finally, an even shorter peptide, based on a less conserved region of the CT end (QRQKKQQTVTLLPAADLDDFSKQ, residues 384-406) was synthesized (CT-peptide)

(Figure S1) (54). Additional information on the $\mathrm{N}$ constructs is provided in the Supplemental material.

HCoV. N FL recombinant proteins from OC43, HKU1, NL63 and 229E HCoVs were codonoptimized for E. coli heterologous expression and His tag-purified as in (25).

\section{Study volunteers and samples}

We analyzed three set of samples, (i) prepandemic plasmas from healthy adults collected before the COVID-19 outbreak (negative controls, $n=128$ ), (ii) pandemic plasmas from health care personnel working at Hospital Clínic in Barcelona (Spain) collected as part of a study on SARS-CoV-2 seroprevalence at the March-April 2020 outbreak $(n=578)$ of which SARS-CoV2 infected cases were asymptomatic or had mild symptoms $(27,50)$, and (iii) pandemic plasmas from 49 COVID-19 patients recruited at the Clínica Universidad de Navarra in Pamplona (Spain), of which 47 had severe symptoms and were hospitalized and 2 had mild symptoms (25).

For the characterization of the immunogenicity of the various SARS-CoV-2 N protein constructs, we used all prepandemic and 104 pandemic samples. For the analysis of HCoV N FL cross-reactivity, we selected 30 prepandemic samples with the highest levels of $\lg G$ to SARS-CoV-2 N FL and 30 prepandemic samples with the lowest levels, among our set of 
medRxiv preprint doi: https://doi.org/10.1101/2020.12.19.20248551; this version posted December 22, 2020. The copyright holder for this

negative controls tested previously (Figure S6) (25). Pandemic samples included: (i) 60 plasmas from individuals with a SARS-CoV-2 infection confirmed by rRT-PCR and seropositive for RBD tested in our prior studies $(27,50)(29$ plasmas with the highest and 31 plasmas with the lowest levels of IgG to SARS-CoV-2 N FL), (ii) 30 plasmas from individuals with a negative rRT-PCR and RBD serology but with high IgG to N FL, and (iii) 7 negative individuals at recruitment M0 who later got infected and seroconverted for RBD at M1. For the analysis of factors associated with antibody levels to SARS-CoV-2 N FL and their kinetics, we tested all the plasma samples available from the cohort of health care workers in Barcelona at baseline $(\mathrm{M} 0=578)$ and 1 and 3 months later $(\mathrm{M} 1=565, \mathrm{M} 3=70)(27,50)$.

\section{Study approval}

The research was carried out according to the principles of the Declaration of Helsinki and informed consent was obtained. Samples analyzed in this study received ethical clearance for immunological evaluation and/or inclusion as controls in immunoassays, and the protocols and informed consent forms were approved by the Institutional Review Board at Hospital Clínic in Barcelona (Refs. CEIC-7455 and HCB/2020/0336) or Universidad de Navarra (Ref. UN/2020/067) prior to study implementation.

\section{Measurement of $\lg M, \lg G$ and $\lg A$ antibodies.}

qSAT assays to measure plasma $\lg \mathrm{G}, \lg \mathrm{A}$ and $\lg \mathrm{M}$ against SARS-CoV-2 $\mathrm{N}$ proteins were performed as reported (27) and analyzed in a Luminex 100/200 instrument. For the assessement of IgG crossreactivity between HCoV and SARS-CoV-2 N proteins, we applied an optimized protocol, as described (25), and samples were analyzed with a FlexMap 3D instead of a Luminex 100/200 instrument, to increase the dynamic quantification range of antibody values in high responders (Figure S7). Briefly, N proteins coupled to magnetic microspheres (Luminex Corporation, Austin, USA) were incubated with plasma samples (1/500 and/or 1/3500 dilutions) or blank controls in 96-well plates. For the CT-peptide, avidinbeads were used that bound the biotin conjugated to a PEG12 biopolymer linked to the 
medRxiv preprint doi: https://doi.org/10.1101/2020.12.19.20248551; this version posted December 22, 2020. The copyright holder for this

peptide, and the coupling performed following manufacturer's instructions. Before multiplexing protein-coupled MagPlex beads, we tested for potential interference among $\mathrm{N}$ constructs comparing to singleplex assays (Figure S7). After sample incubation with beads, plates were washed and a labeled secondary antibody (anti-human $\lg G$, $\lg M$, or $\lg A$ ) was added. Following the last incubation, plates were washed and read in a Luminex XMAP® analyzer. Crude median fluorescent intensities (MFI) and background fluorescence from blank wells were exported using the XPONENT software.

\section{Statistics}

Boxplots and Wilcoxon Rank Sum tests were used to compare antibody levels to each $\mathrm{N}$ protein between study groups. To assess for crossreactivity, we performed correlations (Spearman) and heatmaps of antibody responses to SARS-CoV-2 and HCoV N antigens in prepandemic and pandemic samples separately, stratifying by rRT-PCR positivity and by high vs. low anti-N FL IgG responders, as appropriate. Seropositivity was defined by a cutoff calculated with prepandemic samples as 10 to the mean plus 3 standard deviations of $\log _{10^{-}}$ transformed MFI. A variable called magnitude of responses to HCoV N FL was created by adding up the levels of IgG to the four HCoV N FL. To evaluate the factors associated with levels of antibodies to SARS-CoV-2 N FL, we used Wilcoxon Rank Sum test. The LOESS (locally estimated scatterplot smoothing) method was used to fit a curve to depict kinetics of antibody levels over time. The analysis was carried out using the statistical software R studio version R-4.0.2 (70) (packages used: tidyverse (71), pheatmap (72) and corrplot (73)).

\section{Author contributions}

CD, GM, RA and LI designed the serological study; RS analyzed the data; AJ and MV performed the Luminex experiment; JC, NRM, MP, CC and LI designed and/or produced the recombinant proteins; RLA, LFB and AT performed the peptide studies; MT, FCT, GR, AM, GM, CD and AGB recruited, followed up and sampled human volunteers; AM and CC 
medRxiv preprint doi: https://doi.org/10.1101/2020.12.19.20248551; this version posted December 22, 2020. The copyright holder for this

contributed to rRT-PCR determinations; CD wrote the first manuscript; all authors reviewed and approved the manuscript.

\section{Acknowledgements}

We thank the volunteers who donated blood for COVID-19 studies and the clinical and laboratory staff who participated in the sample collection and processing. Special thanks to

ISGlobal lab colleagues D. Barrios, P. Cisteró, L. Puyol, R.A. Mitchell, C. Jairoce, S. Alonso, J. Moreno, and those involved in data management and/or recruitment of volunteers and patients at the Pamplona and Barcelona hospitals, J.L. del Pozo, M. Fernández-Alonso, S. Sanz, S. Méndez, A. Llupià, E. Chóliz, A. Cruz, A. Figueroa-Romero, S. Folchs, M. Lamoglia, N. Ortega, N. Pey, M. Ribes, N. Rosell, P. Sotomayor, S. Torres, S. Williams, S. Barroso, A. Trilla and P. Varela.

\section{Funding}

The assays development and sample collection were performed with internal funds from the investigators groups and institutions. GM had the support of the Department of Health, Catalan Government (SLT006/17/00109). JC and LI are supported by SAF2016-76080-R grant from the Spanish Ministry of Economy (AEI/FEDER, UE) and by PID2019-110810RBI00 grant from the Spanish Ministry of Science \& Innovation to LI. AT and LFB received support from Departament General de Recerca i Innovació en Salut (GENCAT-DGRISCOVID19), CB 06/06/0028/CIBER de enfermedades respiratorias- Ciberes, ISCIII

(FI19/00090 awarded to RLA) and IDIBAPS group 2.603. ISGlobal receives support from the Spanish Ministry of Science and Innovation through the "Centro de Excelencia Severo Ochoa 2019-2023" Program (CEX2018-000806-S), and support from the Generalitat de Catalunya through the CERCA Program. 
medRxiv preprint doi: https://doi.org/10.1101/2020.12.19.20248551; this version posted December 22, 2020. The copyright holder for this preprint (which was not certified by peer review) is the author/funder, who has granted medRxiv a license to display the preprint in perpetuity.

All rights reserved. No reuse allowed without permission.

\section{FIGURES}

Figure 1. Levels ( $\log _{10}$ median fluorescence intensity, MFI) of antibodies to nucleocapsid (N) SARS-CoV-2 antigens in prepandemic (NC) and pandemic samples. The lower and upper hinges of the boxplots correspond to the $25^{\text {th }}$ and $75^{\text {th }}$ percentiles (IQR) and extend $1.5^{*}$ IQR from the hinge; open circles are means. A) N FL: full-length produced at ISGlobal; N Cterminus [CT] and N N-terminus [NT] domains produced at CRG. NH: non-hospitalized, $\mathrm{H}$ : hospitalized. P values were calculated by the Wilcoxon test. B) N FL and N CT-short from ISGlobal and N CT-peptide. Numerical values on the top of the boxplots are the ratios of the means of positive controls (PC) vs. seropositive cutoff values indicated by black dashed lines, calculated as 10 to the mean plus 3 standard deviations of the $\log _{10}$-transformed MFI of the NC. The grey lines link the samples from the same individuals. PC are the different points of the titration curve corrected to have the same dilution factor. 
medRxiv preprint doi: https://doi.org/10.1101/2020.12.19.20248551; this version posted December 22, 2020. The copyright holder for this preprint (which was not certified by peer review) is the author/funder, who has granted medRxiv a license to display the preprint in perpetuity.

All rights reserved. No reuse allowed without permission.

A.

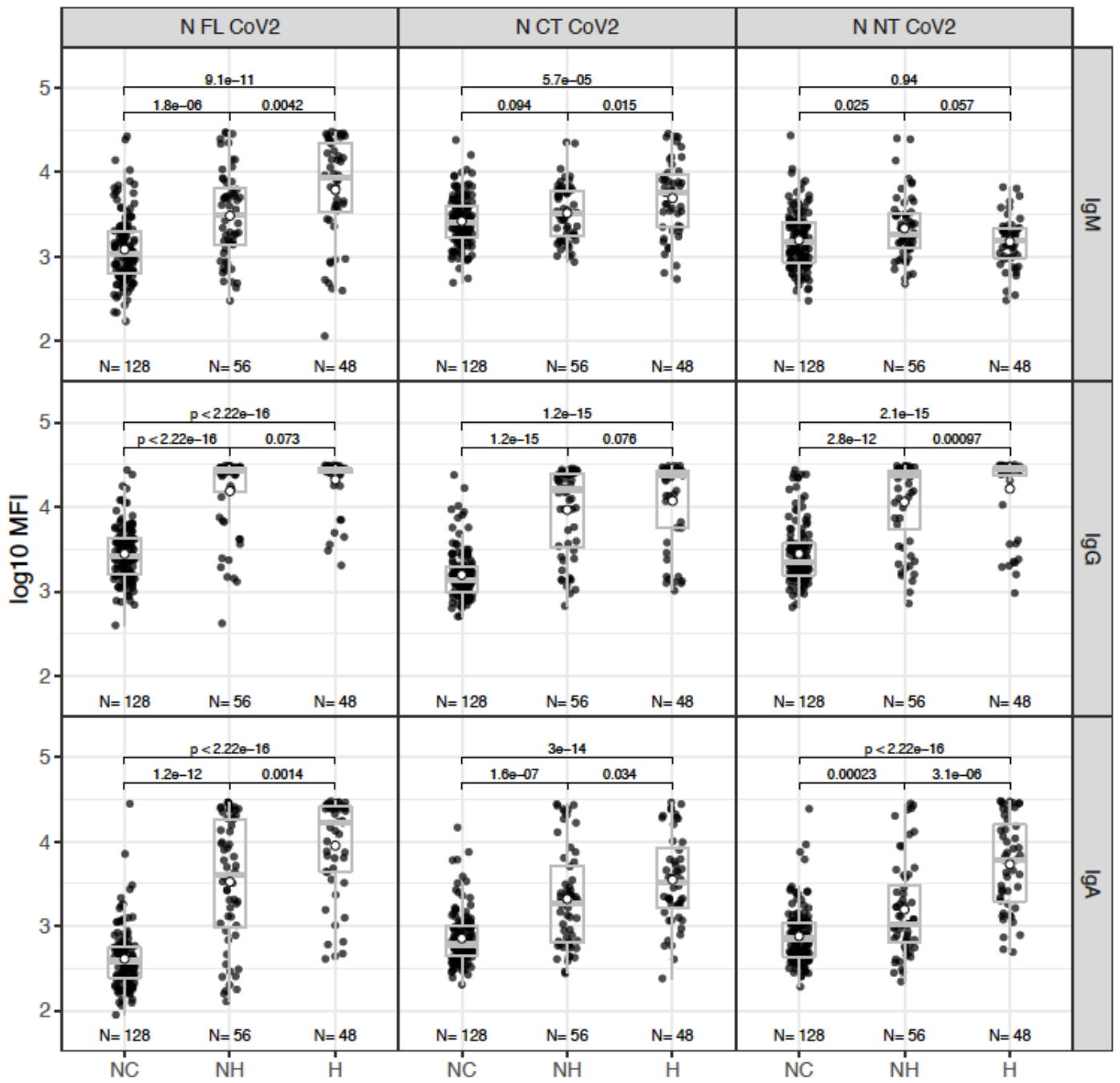

B.

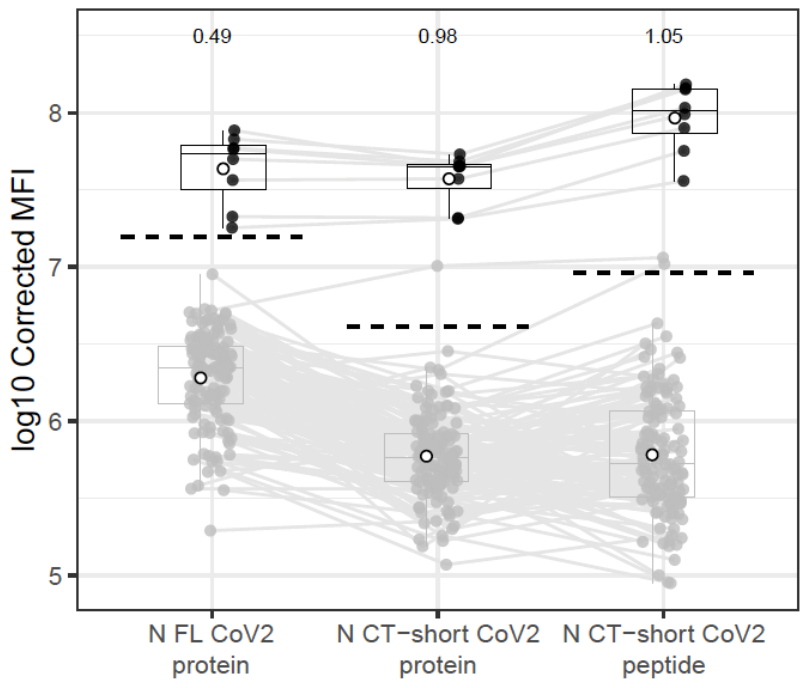

Sample type NC 
medRxiv preprint doi: https://doi.org/10.1101/2020.12.19.20248551; this version posted December 22, 2020. The copyright holder for this preprint (which was not certified by peer review) is the author/funder, who has granted medRxiv a license to display the preprint in perpetuity.

All rights reserved. No reuse allowed without permission.

Figure 2. Levels ( $\log _{10}$ median fluorescence intensity, MFI) of IgG antibodies to $\mathrm{N}$ antigens of human coronaviruses. A) Plasmas from prepandemic (NC) and pandemic (rRT-PCR positive vs. negative) individuals. Plasmas stratified according to low vs. high IgG responses to SARS-CoV-2 N FL in B) prepandemic and C) pandemic rRT-PCR positive. Boxplots indicate median and IQR, open circles are means, and $p$ values were calculated by Wilcoxon test.

A.

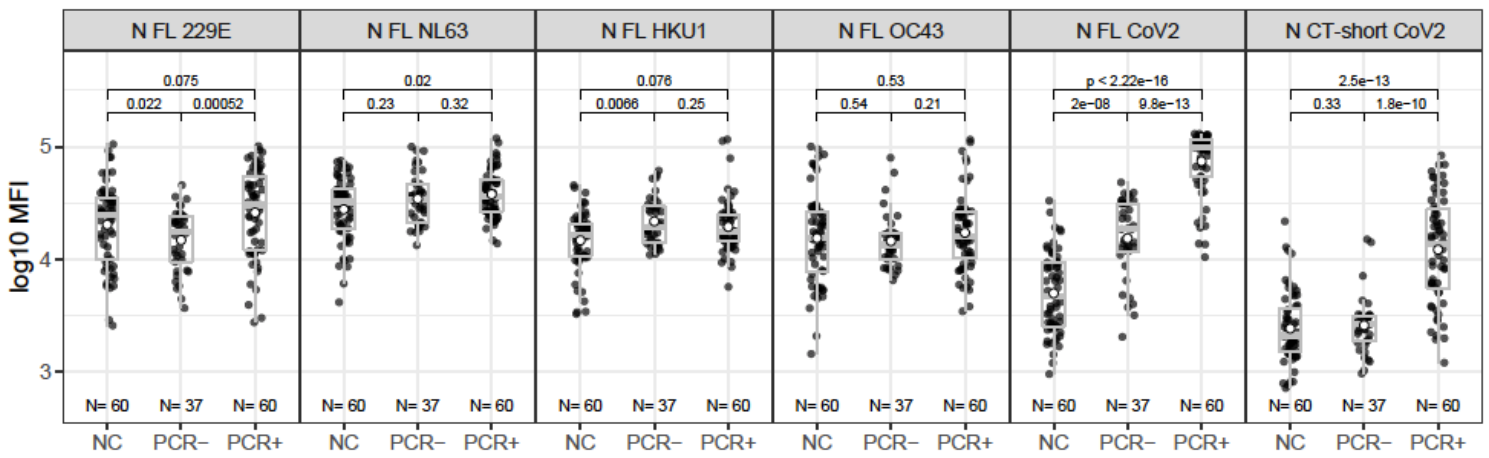

B.

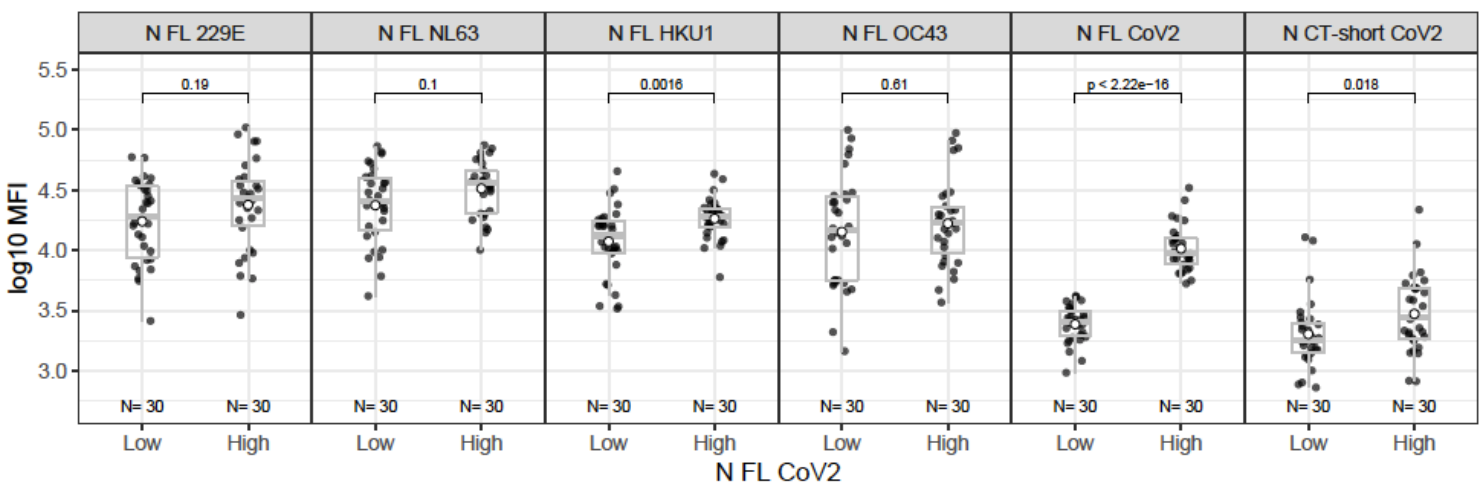

C.

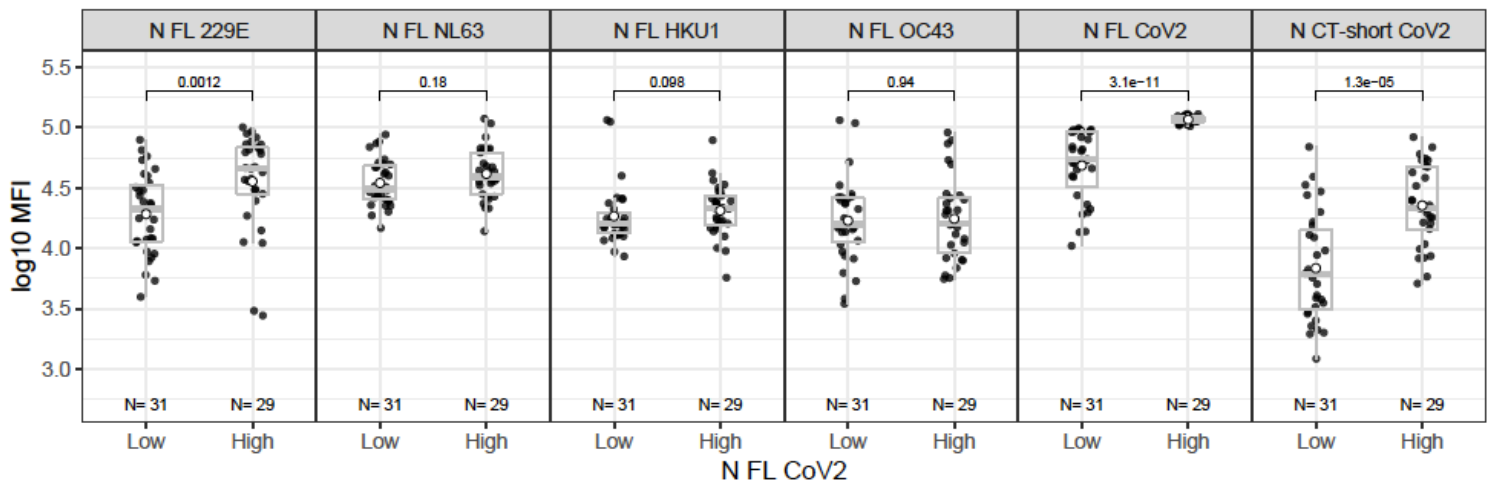


medRxiv preprint doi: https://doi.org/10.1101/2020.12.19.20248551; this version posted December 22, 2020. The copyright holder for this preprint (which was not certified by peer review) is the author/funder, who has granted medRxiv a license to display the preprint in perpetuity.

All rights reserved. No reuse allowed without permission.

Figure 3. Correlations of plasma IgG levels $\left(\log _{10} \mathrm{MFI}\right)$ to SARS-CoV-2 and HCoV N antigens. A) Pandemic and prepandemic samples. B) Pandemic rRT-PCR positive and negative. C) Magnitude of response to HCoV in pandemic and prepandemic samples. Rho and $p$ values are calculated by Spearman, shaded areas represent 0.95 confidence intervals.

A.

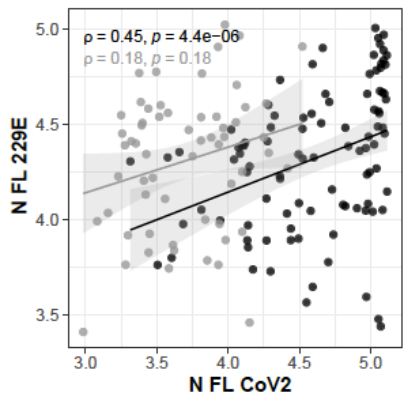

Sample type $\rightarrow$ Pandemic $\rightarrow$ Prepandemic
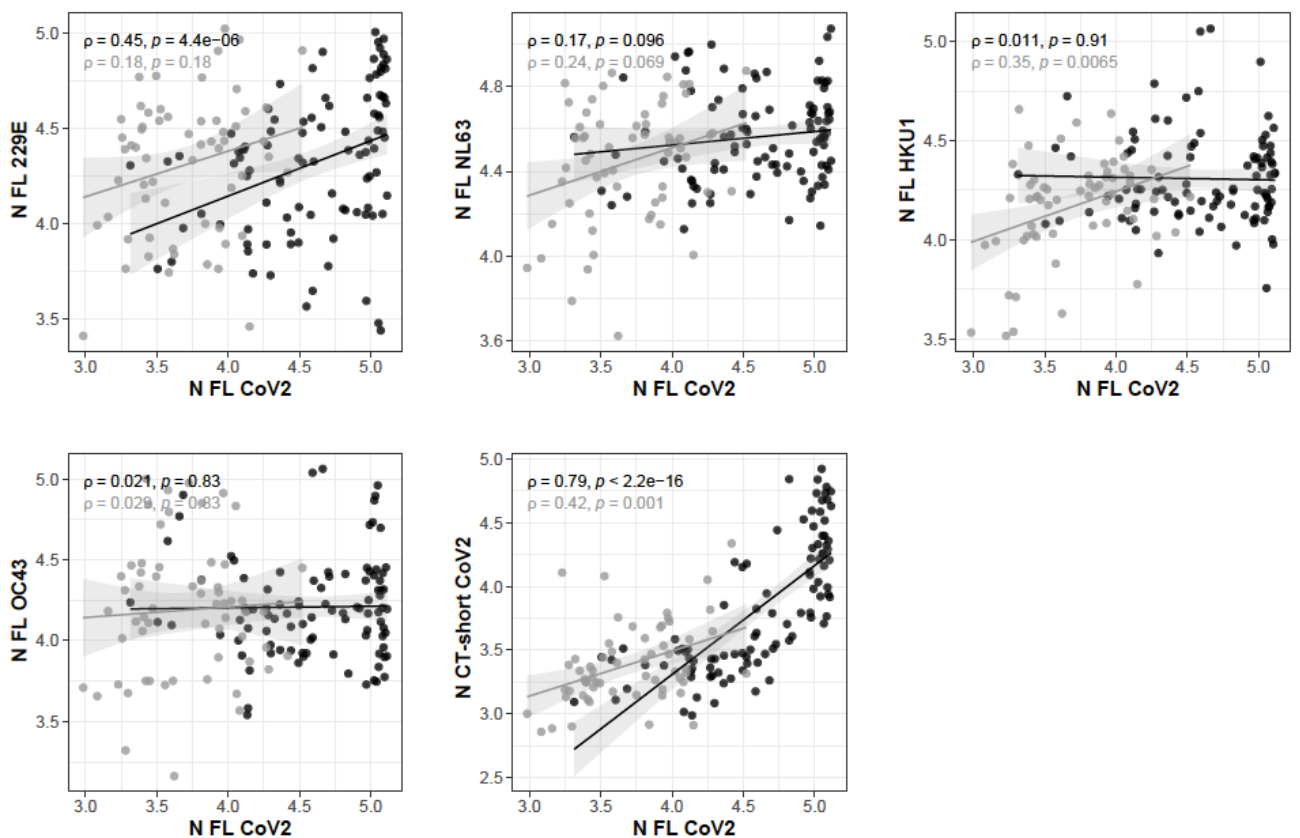

B.
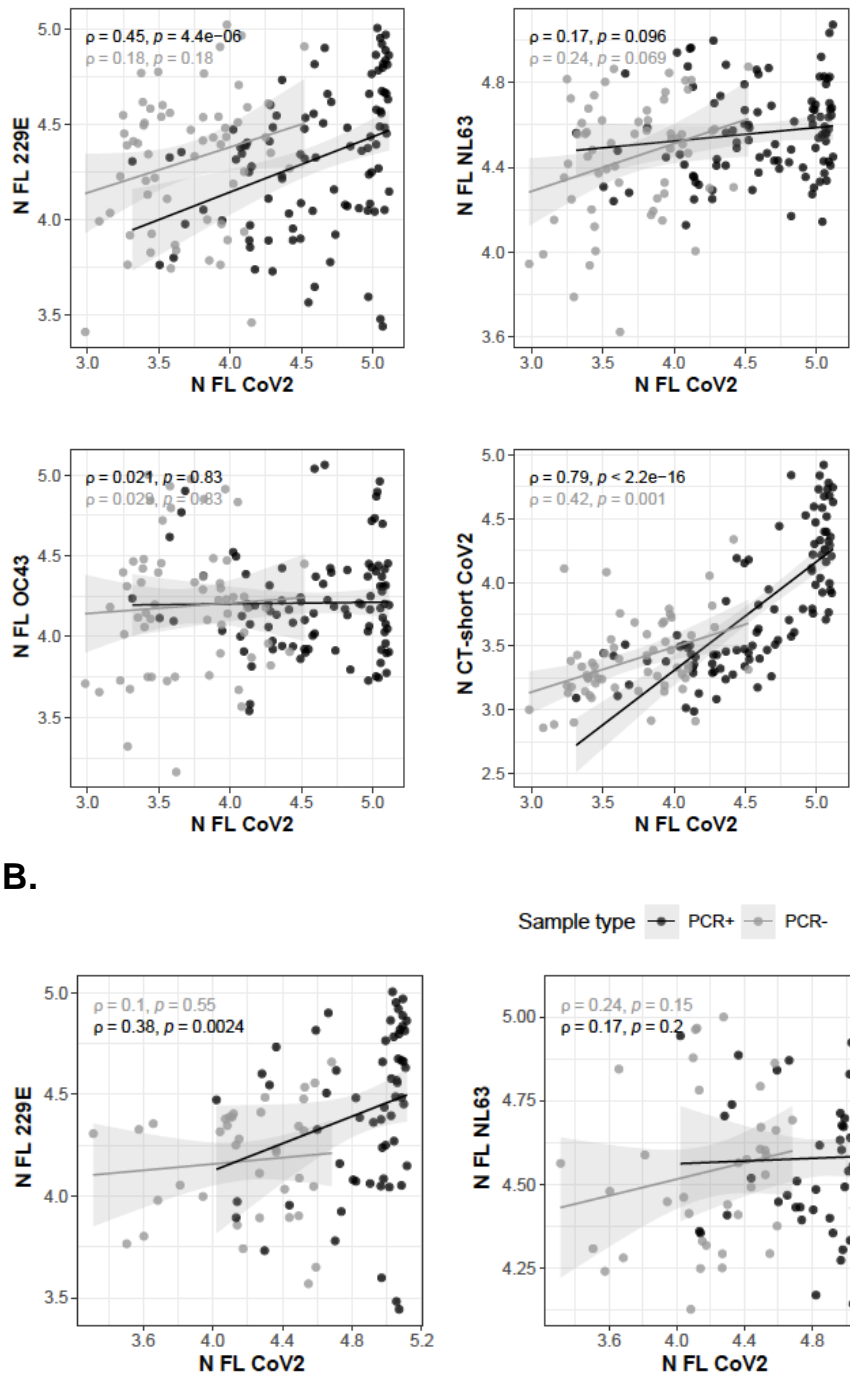

B.

Sample type $\rightarrow$ PCR+ $\rightarrow$ PCR-
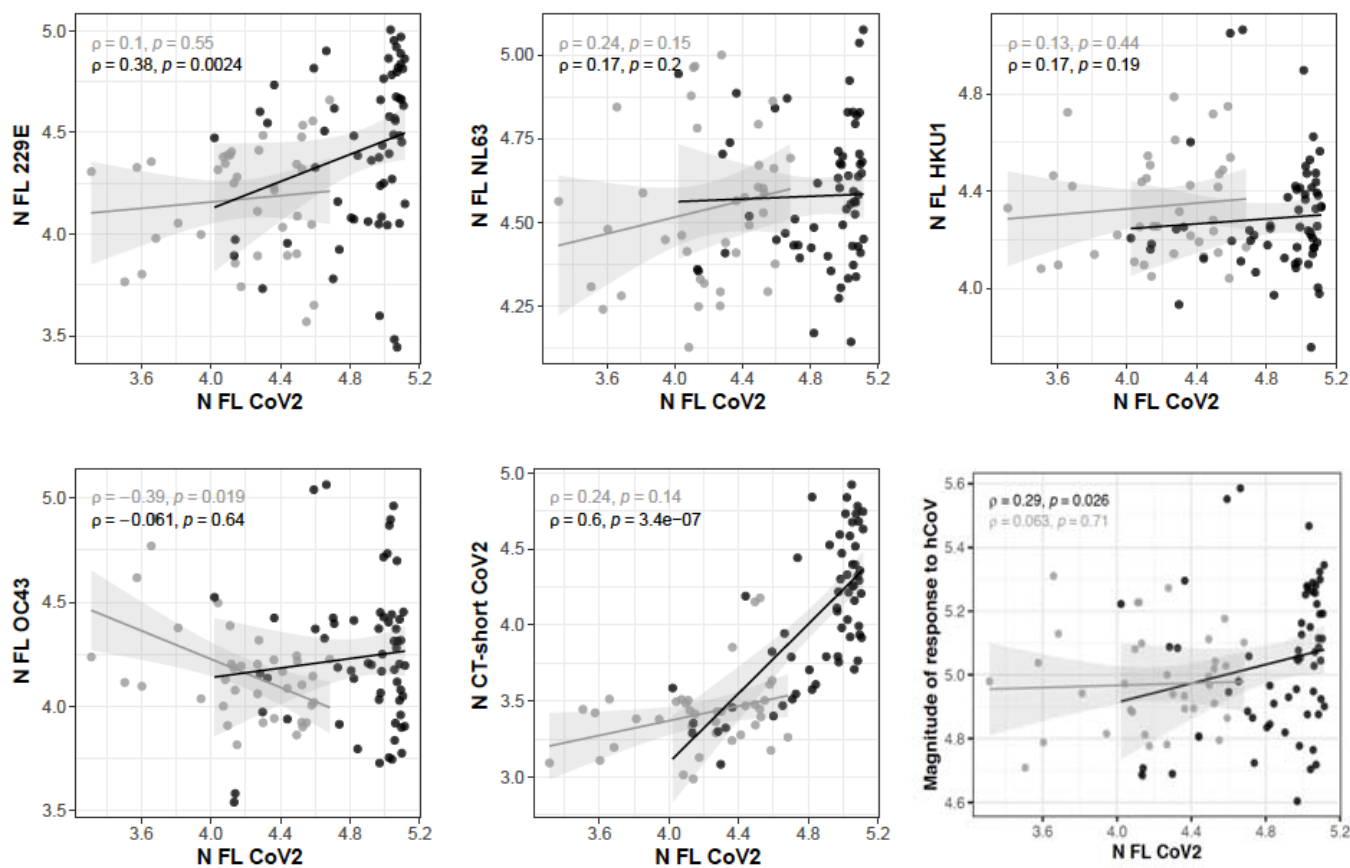
medRxiv preprint doi: https://doi.org/10.1101/2020.12.19.20248551; this version posted December 22, 2020. The copyright holder for this preprint (which was not certified by peer review) is the author/funder, who has granted medRxiv a license to display the preprint in perpetuity.

All rights reserved. No reuse allowed without permission.

C.
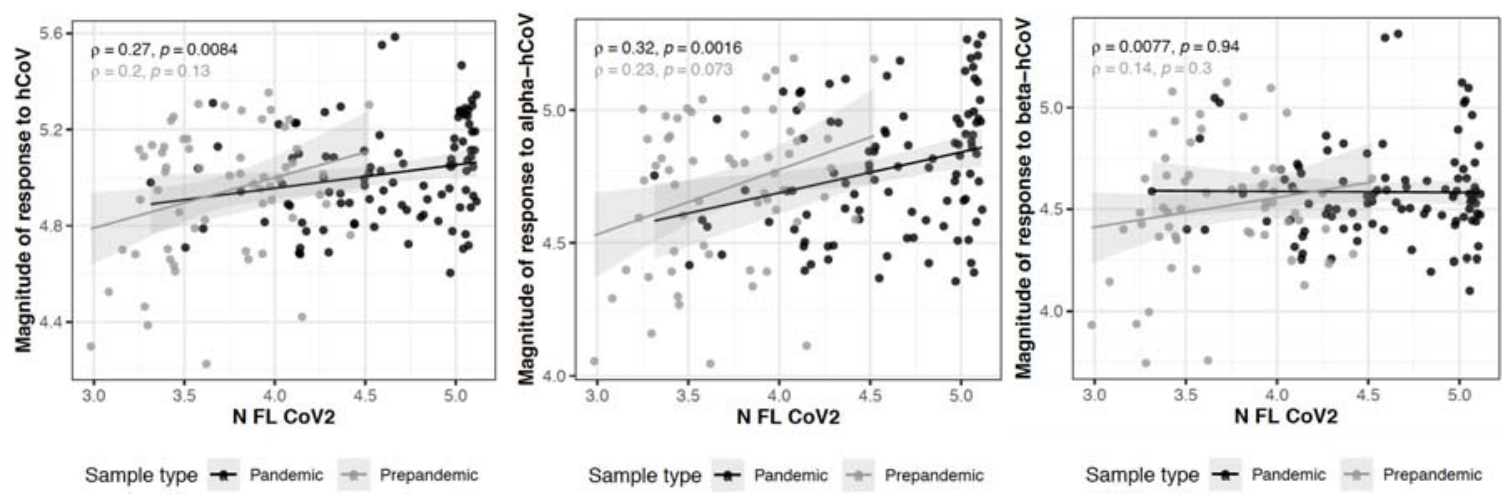

Sample type $\#$ Pandemic - Prepandemic

Sample type *-Pandemic * Prepandemic

Sample type $\approx$ Pandemic $\#$ Prepandemic 
medRxiv preprint doi: https://doi.org/10.1101/2020.12.19.20248551; this version posted December 22, 2020. The copyright holder for this preprint (which was not certified by peer review) is the author/funder, who has granted medRxiv a license to display the preprint in perpetuity. All rights reserved. No reuse allowed without permission.

Figure 4. Change in antibody levels to human coronavirus nucleocapsid $(\mathrm{N})$ proteins from baseline (M0) to one month later (M1) depending on the rRT-PCR SARS-CoV-2 infection and seropositivity to RBD status (positive + or negative -).

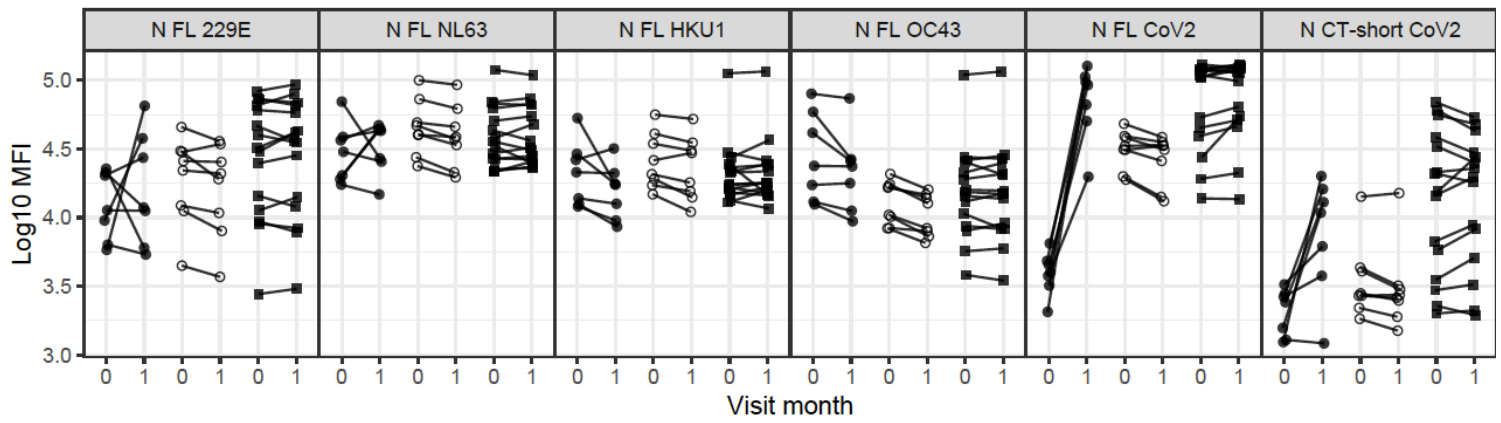

Sample type - M0: PCR- Sero- \& M1: PCR+ Sero+ o M0 \& M1: PCR- Sero- - M0 \& M1: PCR+ Sero+ 
medRxiv preprint doi: https://doi.org/10.1101/2020.12.19.20248551; this version posted December 22, 2020. The copyright holder for this preprint (which was not certified by peer review) is the author/funder, who has granted medRxiv a license to display the preprint in perpetuity.

All rights reserved. No reuse allowed without permission.

Figure 5. Kinetics of antibody responses to SARS-CoV-2 nucleocapsid (N) full-length protein in a cohort of health care workers with any evidence of infection (rRT-PCR positive or RBD antibody positive for any isotype) at any visit (month [M]0), M1 and M3). A) Antibody levels by visit and stratified by symptoms. B) Antibody kinetics since onset of symptoms. C) Antibody kinetics since first rRT-PCR positive. The curves represent the kinetics of the samples over time and was calculated by the LOESS (locally estimated scatterplot smoothing) method. The shaded area represents the 0.95 confidence intervals.

A.

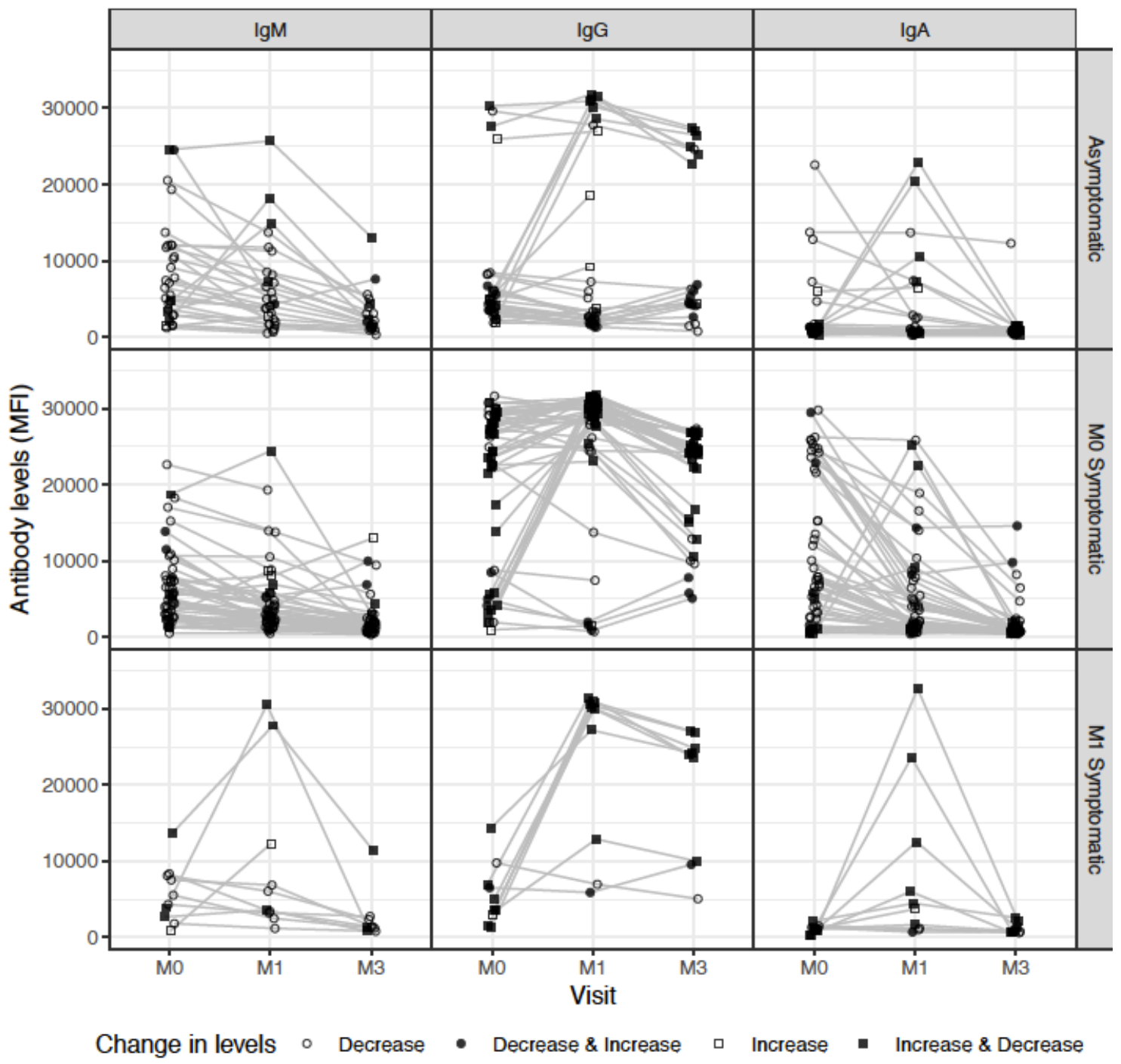


medRxiv preprint doi: https://doi.org/10.1101/2020.12.19.20248551; this version posted December 22, 2020. The copyright holder for this preprint (which was not certified by peer review) is the author/funder, who has granted medRxiv a license to display the preprint in perpetuity.

All rights reserved. No reuse allowed without permission.

B
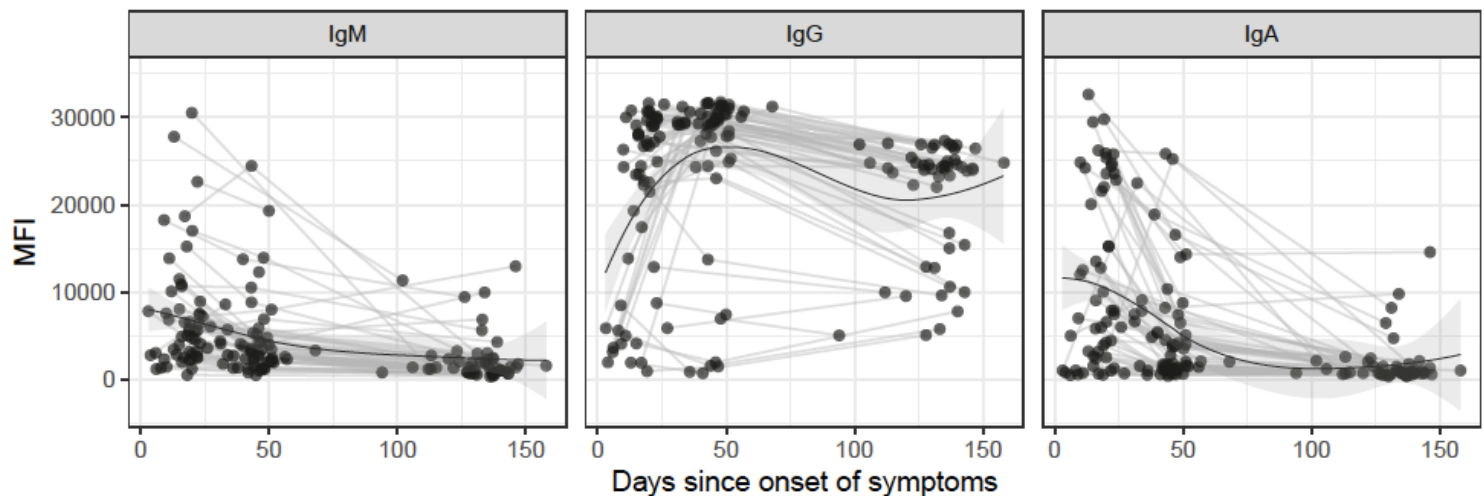

C.
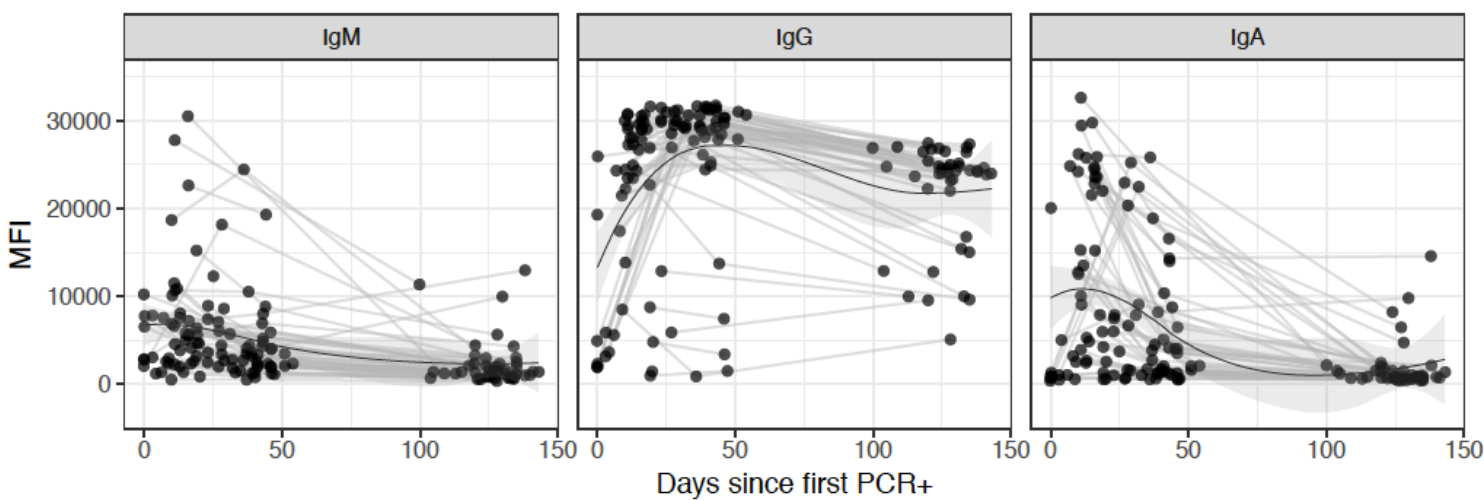
medRxiv preprint doi: https://doi.org/10.1101/2020.12.19.20248551; this version posted December 22, 2020. The copyright holder for this preprint (which was not certified by peer review) is the author/funder, who has granted medRxiv a license to display the preprint in perpetuity.

All rights reserved. No reuse allowed without permission.

Figure 6. Factors affecting the levels of antibodies to SARS-CoV-2 nucleocapsid (N) fulllength antigen. Boxplots indicate median and IQR, open circles are means, and $p$ values were calculated by Wilcoxon test.

A.

Symptoms (accumulated any evidence of infection M0 \& M1)

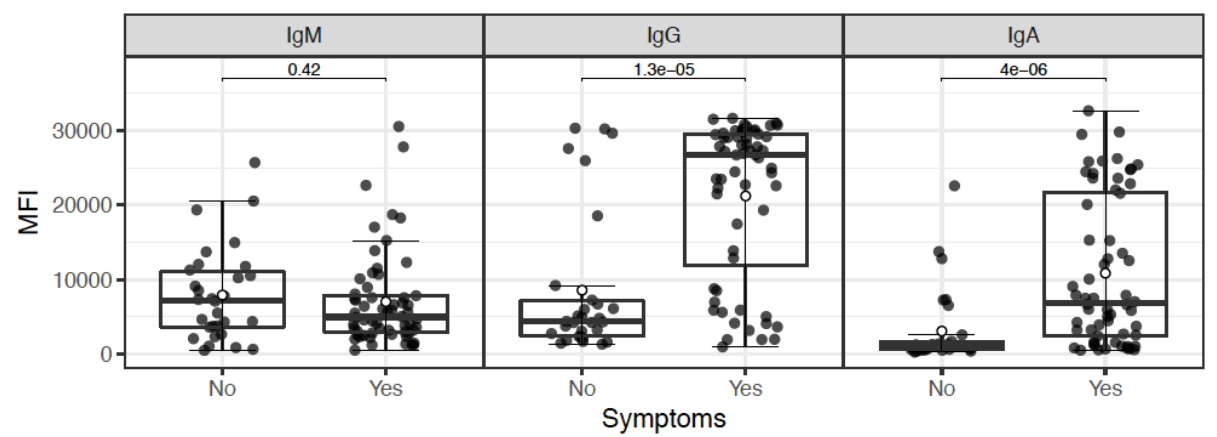

Duration of symptoms (accumulated any evidence of infection M0 \& M1)

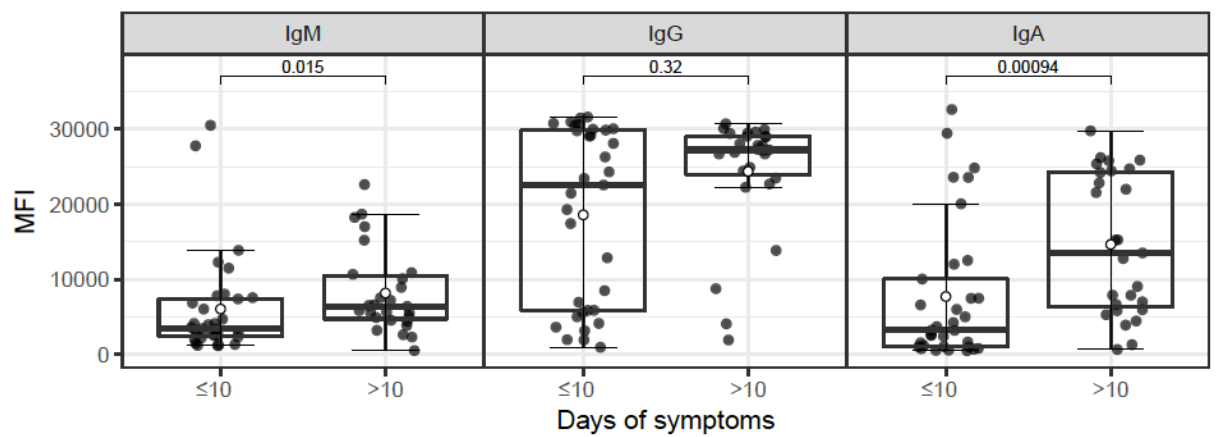

B.

Age (accumulated any evidence of infection M0 \& M1)

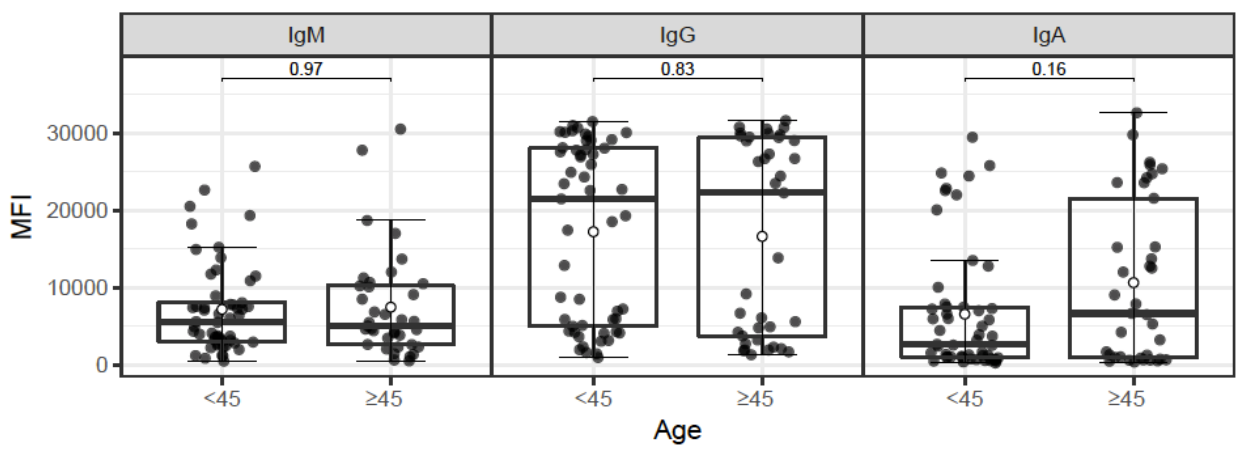

Sex (accumulated any evidence of infection M0 \& M1)

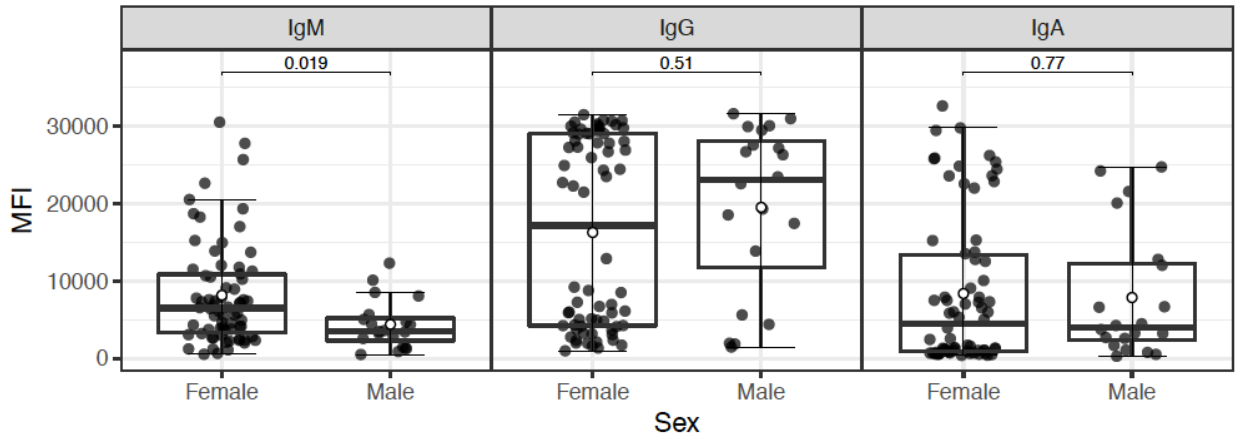


medRxiv preprint doi: https://doi.org/10.1101/2020.12.19.20248551; this version posted December 22, 2020. The copyright holder for this preprint (which was not certified by peer review) is the author/funder, who has granted medRxiv a license to display the preprint in perpetuity.

All rights reserved. No reuse allowed without permission.

\section{REFERENCES}

1. Mittal A et al. COVID-19 pandemic: Insights into structure, function, and hACE2 receptor recognition by SARS-CoV-2. PLoS Pathog. 2020;16(8):e1008762.

2. Zeng $W$ et al. Biochemical characterization of SARS-CoV-2 nucleocapsid protein.

Biochem. Biophys. Res. Commun. 2020;527(3):618-623.

3. Shang J et al. Cell entry mechanisms of SARS-CoV-2. Proc. Natl. Acad. Sci. U. S. A. 2020;117(21):11727-11734.

4. Shang $\mathrm{J}$ et al. Structural basis of receptor recognition by SARS-CoV-2. Nature 2020;581(7807):221-224.

5. Wang $Q$ et al. Structural and Functional Basis of SARS-CoV-2 Entry by Using Human ACE2. Cell 2020;181:894-904.

6. Krammer F. SARS-CoV-2 vaccines in development. Nature 2020;586(7830):516-527.

7. Poland GA, Ovsyannikova IG, Kennedy RB. SARS-CoV-2 immunity: review and

applications to phase 3 vaccine candidates. Lancet (London, England)

2020;396(10262):1595-1606.

8. Bryan A et al. Performance Characteristics of the Abbott Architect SARS-CoV-2 IgG Assay and Seroprevalence Testing in Idaho. J. Clin. Microbiol. [published online ahead of print: January 1, 2020]; doi:10.1101/2020.04.27.20082362

9. Chan CW et al. Analytical and Clinical Evaluation of the Automated Elecsys Anti-SARSCoV-2 Antibody Assay on the Roche cobas e602 Analyzer. Am. J. Clin. Pathol.

2020;154(5):620-626.

10. Muench $P$ et al. Development and Validation of the Elecsys Anti-SARS-CoV-2

Immunoassay as a Highly Specific Tool for Determining Past Exposure to SARS-CoV-2. J. Clin. Microbiol. 2020;58(10). doi:10.1128/JCM.01694-20

11. Beavis KG et al. Evaluation of the EUROIMMUN Anti-SARS-CoV-2 ELISA Assay for detection of IgA and IgG antibodies. J. Clin. Virol. 2020;129:104468.

12. Tan Y-J, Lim SG, Hong W. Characterization of viral proteins encoded by the SARScoronavirus genome. Antiviral Res. 2005;65(2):69-78.

13. Ahmed SF, Quadeer AA, McKay MR. Preliminary identification of potential vaccine targets for the COVID-19 coronavirus (SARS-CoV-2) based on SARS-CoV immunological studies. Viruses 2020;12(3). doi:10.1101/2020.02.03.933226

14. Lee $S$, Lee $C$. Functional characterization and proteomic analysis of the nucleocapsid protein of porcine deltacoronavirus. Virus Res. 2015;208:136-145.

15. Leung DTM et al. Antibody response of patients with severe acute respiratory syndrome (SARS) targets the viral nucleocapsid. J. Infect. Dis. 2004;190(2):379-386.

16. Burbelo PD et al. Sensitivity in Detection of Antibodies to Nucleocapsid and Spike Proteins of Severe Acute Respiratory Syndrome Coronavirus 2 in Patients With Coronavirus Disease 2019. J. Infect. Dis. 2020;222(2):206-213.

17. Atyeo C et al. Distinct Early Serological Signatures Track with SARS-CoV-2 Survival. Immunity 2020;53(3):524-532.e4.

18. Weisberg SP et al. Distinct antibody responses to SARS-CoV-2 in children and adults across the COVID-19 clinical spectrum. Nat. Immunol. [published online ahead of print: November 2020]; doi:10.1038/s41590-020-00826-9

19. McBride R, van Zyl M, Fielding BC. The coronavirus nucleocapsid is a multifunctional protein. Viruses 2014;6(8):2991-3018.

20. Cong $Y$ et al. Nucleocapsid Protein Recruitment to Replication-Transcription Complexes Plays a Crucial Role in Coronaviral Life Cycle. J. Virol. 2020;94(4):e01925-19.

21. Zhou B et al. The Nucleocapsid Protein of Severe Acute Respiratory Syndrome Coronavirus Inhibits Cell Cytokinesis and Proliferation by Interacting with Translation Elongation Factor 1a. J. Virol. 2008;82(14):6962 LP - 6971.

22. Surjit M, Liu B, Chow VTK, Lal SK. The nucleocapsid protein of severe acute respiratory syndrome-coronavirus inhibits the activity of cyclin-cyclin-dependent kinase complex and blocks S phase progression in mammalian cells. J. Biol. Chem. 2006;281(16):10669-10681. 23. Chang C, Hou M-H, Chang C-F, Hsiao C-D, Huang T. The SARS coronavirus 
medRxiv preprint doi: https://doi.org/10.1101/2020.12.19.20248551; this version posted December 22, 2020. The copyright holder for this preprint (which was not certified by peer review) is the author/funder, who has granted medRxiv a license to display the preprint in perpetuity.

All rights reserved. No reuse allowed without permission.

nucleocapsid protein - Forms and functions. Antiviral Res. 2014;103:39-50.

24. Chen Z et al. Antigenicity Analysis of Different Regions of the Severe Acute Respiratory Syndrome Coronavirus Nucleocapsid Protein. Clin. Chem. 2004;50(6):988-995.

25. Dobaño $C$ et al. Highly sensitive and specific multiplex antibody assays to quantify immunoglobulins M, A and G against SARS-CoV-2 antigens. J. Clin. Microbiol. 2020;DOI: 10.1101/2020.06.11.147363.

26. Woo PCY et al. Detection of specific antibodies to severe acute respiratory syndrome (SARS) coronavirus nucleocapsid protein for serodiagnosis of SARS coronavirus pneumonia. J. Clin. Microbiol. 2004;42(5):2306-2309.

27. Garcia-Basteiro AL et al. Seroprevalence of antibodies against SARS-CoV-2 among health care workers in a large Spanish reference hospital. Nat. Commun. 2020;11(1):3500. 28. Meyer B, Drosten C, Müller MA. Serological assays for emerging coronaviruses: challenges and pitfalls. Virus Res. 2014;194:175-183.

29. Khan S et al. Analysis of Serologic Cross-Reactivity Between Common Human Coronaviruses and SARS-CoV-2 Using Coronavirus Antigen Microarray. bioRxiv [published online ahead of print: January 1, 2020]; doi:10.1101/2020.03.24.006544

30 . Che $X-Y$ et al. Antigenic cross-reactivity between severe acute respiratory syndromeassociated coronavirus and human coronaviruses $229 \mathrm{E}$ and OC43. J. Infect. Dis. 2005;191(12):2033-2037.

31. Okba NMA et al. Severe Acute Respiratory Syndrome Coronavirus 2-Specific Antibody Responses in Coronavirus Disease 2019 Patients. Emerg. Infect. Dis. 2020;26(7). doi:10.3201/eid2607.200841

32. Basavaraju S V et al. Serologic testing of U.S. blood donations to identify SARS-CoV-2reactive antibodies: December 2019-January 2020. Clin. Infect. Dis. [published online ahead of print: November 30, 2020]; doi:10.1093/cid/ciaa1785

33. Yu $\mathrm{F}$ et al. Evaluation of inapparent nosocomial severe acute respiratory syndrome coronavirus infection in Vietnam by use of highly specific recombinant truncated nucleocapsid protein-based enzyme-linked immunosorbent assay. Clin. Diagn. Lab. Immunol. 2005;12(7):848-854.

34. Yamaoka Y et al. Whole Nucleocapsid Protein of Severe Acute Respiratory Syndrome Coronavirus 2 May Cause False-Positive Results in Serological Assays. Clin. Infect. Dis. [published online ahead of print: May 23, 2020]; doi:10.1093/cid/ciaa637

35. Grifoni A et al. Targets of T Cell Responses to SARS-CoV-2 Coronavirus in Humans with COVID-19 Disease and Unexposed Individuals. Cell 2020;181(7):1489-1501.e15.

36. Braun $\mathrm{J}$ et al. SARS-CoV-2-reactive T cells in healthy donors and patients with COVID19. Nature 2020;587(7833):270-274.

37. Bacher $\mathrm{P}$ et al. Low avidity CD4+ T cell responses to SARS-CoV-2 in unexposed individuals and humans with severe COVID-19. Immunity [published online ahead of print: 2020]; doi:https://doi.org/10.1016/j.immuni.2020.11.016

38. Le Bert $\mathrm{N}$ et al. Different pattern of pre-existing SARS-COV-2 specific T cell immunity in SARS-recovered and uninfected individuals. Prepr. bioRxiv [published online ahead of print: 2020]; doi:10.1101/2020.05.26.115832

39. Nelde A et al. SARS-CoV-2-derived peptides define heterologous and COVID-19induced T cell recognition. Nat. Immunol. [published online ahead of print: September 2020]; doi:10.1038/s41590-020-00808-x

40. Sagar $\mathrm{M}$ et al. Recent endemic coronavirus infection is associated with less severe COVID-19. J. Clin. Invest. [published online ahead of print: September 2020]; doi:10.1172/JCl143380

41. Yuki K, Fujiogi M, Koutsogiannaki S. COVID-19 pathophysiology: A review. Clin. Immunol. 2020;215:108427.

42. $\mathrm{Ng} \mathrm{KW}$ et al. Preexisting and de novo humoral immunity to SARS-CoV-2 in humans. Science (80-. ). 2020; eabe1107.

43. Yang $\mathrm{F}$ et al. Shared B cell memory to coronaviruses and other pathogens varies in human age groups and tissues. bioRxiv [published online ahead of print: January 1, 2020]; doi:10.1101/2020.12.01.407015 
medRxiv preprint doi: https://doi.org/10.1101/2020.12.19.20248551; this version posted December 22, 2020. The copyright holder for this preprint (which was not certified by peer review) is the author/funder, who has granted medRxiv a license to display the preprint in perpetuity. All rights reserved. No reuse allowed without permission.

44. Vatti A et al. Original antigenic sin: A comprehensive review. J. Autoimmun. 2017;83:1221.

45. Aydillo T et al. Antibody Immunological Imprinting on COVID-19 Patients. medRxiv [published online ahead of print: January 1, 2020]; doi:10.1101/2020.10.14.20212662 46. Arvin AM et al. A perspective on potential antibody-dependent enhancement of SARSCoV-2. Nature 2020;584(7821):353-363.

47. Lee WS, Wheatley AK, Kent SJ, DeKosky BJ. Antibody-dependent enhancement and SARS-CoV-2 vaccines and therapies. Nat. Microbiol. 2020;5(10):1185-1191.

48. Selva KJ et al. Distinct systems serology features in children, elderly and COVID patients. medRxiv [published online ahead of print: January 1, 2020];

doi:10.1101/2020.05.11.20098459

49. Westerhuis BM et al. Severe COVID-19 patients display a back boost of seasonal coronavirus-specific antibodies. medRxiv [published online ahead of print: January 1, 2020]; doi:10.1101/2020.10.10.20210070

50. Moncunill G et al. SARS-CoV-2 seroprevalence and antibody kinetics among health care workers in a Spanish hospital after three months of follow-up. J. Infect. Dis. [published online ahead of print: January 1, 2020]; doi:10.1093/infdis/jiaa696

51. Lee H-K et al. Detection of antibodies against SARS-Coronavirus using recombinant truncated nucleocapsid proteins by ELISA. J. Microbiol. Biotechnol. 2008;18(10):1717-1721. 52. Dutta NK et al. Search for potential target site of nucleocapsid gene for the design of an epitope-based SARS DNA vaccine. Immunol. Lett. 2008;118(1):65-71.

53. Lee HK et al. Production of specific antibodies against SARS-coronavirus nucleocapsid protein without cross reactivity with human coronaviruses 229E and OC43.. J. Vet. Sci. 2010;11(2):165-167.

54. Wang $\mathrm{J}$ et al. Assessment of immunoreactive synthetic peptides from the structural proteins of severe acute respiratory syndrome coronavirus. Clin. Chem. 2003;49(12):19891996.

55. Grifoni A et al. A Sequence Homology and Bioinformatic Approach Can Predict Candidate Targets for Immune Responses to SARS-CoV-2. Cell Host Microbe 2020;27(4):671-680.e2.

56. Edridge AWD et al. Seasonal coronavirus protective immunity is short-lasting. Nat. Med. 2020;26(11):1691-1693.

57. Gao W et al. Effects of a SARS-associated coronavirus vaccine in monkeys. Lancet (London, England) 2003;362(9399):1895-1896.

58 . Okada $\mathrm{M}$ et al. The development of vaccines against SARS corona virus in mice and SCID-PBL/hu mice. Vaccine 2005;23(17-18):2269-2272.

59. Van Elslande $\mathrm{J}$ et al. Antibody response against SARS-CoV-2 spike protein and nucleoprotein evaluated by four automated immunoassays and three ELISAs. Clin. Microbiol. Infect. 2020;26(11):1557.e1-1557.e7.

60. de Assis RR et al. Analysis of SARS-CoV-2 Antibodies in COVID-19 Convalescent Plasma using a Coronavirus Antigen Microarray. bioRxiv Prepr. Serv. Biol. 2020; doi:10.1101/2020.04.15.043364

61. Huang AT et al. A systematic review of antibody mediated immunity to coronaviruses: kinetics, correlates of protection, and association with severity. Nat. Commun. 2020;11(1):4704.

62. Su $\mathrm{S}$ et al. Epidemiology, Genetic Recombination, and Pathogenesis of Coronaviruses. Trends Microbiol. 2016;24(6):490-502.

63. Kissler SM, Tedijanto C, Goldstein E, Grad YH, Lipsitch M. Projecting the transmission dynamics of SARS-CoV-2 through the postpandemic period. Science (80-. ).

2020;368(6493):860 LP - 868.

64. Trivedi SU et al. Development and Evaluation of a Multiplexed Immunoassay for Simultaneous Detection of Serum IgG Antibodies to Six Human Coronaviruses. Sci. Rep. 2019;9(1):1390.

65. He Y, Zhou Y, Siddiqui P, Niu J, Jiang S. Identification of Immunodominant Epitopes on the Membrane Protein of the Severe Acute Respiratory Syndrome-Associated Coronavirus. 
medRxiv preprint doi: https://doi.org/10.1101/2020.12.19.20248551; this version posted December 22, 2020. The copyright holder for this preprint (which was not certified by peer review) is the author/funder, who has granted medRxiv a license to display the preprint in perpetuity. All rights reserved. No reuse allowed without permission.

J. Clin. Microbiol. 2005;43(8):3718 LP - 3726.

66. Nguyen-Contant $P$ et al. S Protein-Reactive IgG and Memory B Cell Production after Human SARS-CoV-2 Infection Includes Broad Reactivity to the S2 Subunit. MBio 2020;11(5):e01991-20.

67. Anderson EM et al. Seasonal human coronavirus antibodies are boosted upon SARSCoV-2 infection but not associated with protection. medRxiv [published online ahead of print: January 1, 2020]; doi:10.1101/2020.11.06.20227215

68. Kim D, Quinn J, Pinsky B, Shah NH, Brown I. Rates of Co-infection Between SARS-CoV2 and Other Respiratory Pathogens. JAMA 2020;323(20):2085-2086.

69. Gordon DE et al. A SARS-CoV-2 protein interaction map reveals targets for drug repurposing. Nature 2020;583(7816):459-468.

70. R Core Team. R: A Language and Environment for Statistical Computing

71. Wickham H et al. Welcome to the Tidyverse. J. Open Source Softw. 2019;4(43):1686. https://doi.org/10.21105/joss.01686.

72. Kolde R. Package 'pheatmap': pretty heat map2019;1-8. https://doi.org/10.21105/joss.01686.

73. Wei T et al. R package "corrplot": Visualization of a Correlation Matrix. Statistician 2017;56:316-324. https://github.com/taiyun/corrplot. 